\title{
DNA Extraction from Insects by Using Different Techniques: A Review
}

\author{
Usman Asghar*, Muhammad Faheem Malik, Fakhra Anwar, Ayesha Javed, Ali Raza \\ Department of Zoology, University of Gujrat, Hafiz Hayat Campus, Gujrat, Pakistan \\ Email: ${ }^{*}$ usmanasghar228@gmail.com
}

Received 22 July 2015; accepted 23 August 2015; published 26 August 2015

Copyright (C) 2015 by authors and Scientific Research Publishing Inc.

This work is licensed under the Creative Commons Attribution International License (CC BY). http://creativecommons.org/licenses/by/4.0/

(c) (i) Open Access

\section{Abstract}

This review paper was prepared at Department of Zoology, University of Gujrat, Pakistan during 2014-2015. The data for the two decades, DNA Extraction from Insects by Using Different Techniques was compiled through a thorough review of many research articles published in various journals of international repute. Insects are very important economically and ecologically for human due to their various roles, as pests, decomposer in nutrition cycle, vector for the transmission of certain diseases and a source of medically and economically important products. To identify insect, and for research on their role, different molecular techniques are used. For each molecular technique, high quality DNA is required, which is extracted from the insects by different techniques. The selection of DNA extraction technique is depended upon specimen under study, time required for extraction, economical stander of technique due to reagents and equipment used for extraction and most importantly extracted DNA quality. In this paper, most frequently used techniques for DNA extraction from insect with different size and condition are outlined. This paper is only a guide for these techniques and we describe them briefly.

\section{Keywords}

Extraction, Techniques, Reagents

\section{Introduction}

Some insects are very important economically due to their pests’ activities, to control them their accurate identification is essential. To identify these insect rapidly and accurately, their short DNA sequence are used in DNA barcoding, where these DNA sequence are species genetic identification tags. In that type of identification, the first step is the DNA extraction [1].

${ }^{*}$ Corresponding author. 
Insects play important role in forest ecosystem, they feed on wood and play its role in nutrient cycle. Some are pests on forest and their product in forest and timber industry, due to their economic and ecological role research conducted on control of these insect, by study systematic, ecological, phylogenetic and molecular genetics. For all these research, high quality DNA is extracted [2].

Ecological studies conduct on recently-extinct species and those extinct species which are not collected as living specimen and present in copal (sub-fossilized resin) form, copal are used for extracting DNA from them and study their sequence by GS Junior 454 System [3]. Insect ecology helps to understand insect evolution and diversity, and their role as trophic link between components of habitat. Phenotypic markers like body spots and bands, hairs and spines and eye color are used to study genetic inheritance, mating behavioral and dispersal pattern. But use of this marker is time consuming, and error contained process because these are infrequent and difficult to score. In more advancement protein, markers are used to study pathogen identification and insecticide resistance. But in modern time, DNA marker are used to study Mating, parentage and kinship, Insect plant interaction, Insect pathogen interaction, Insecticide resistance, Prey, predator and parasites, genome and QTL mapping, Comparative genomics and cytogenetic of insect. DNA markers are more important because DNA is more stable then protein and help to detect variation due to mutation on intron or in gene codon [4].

On the other hand, some insect species studied in relation to transmission of dengue virus, like Ades aegypti and A. albopictus. To conduct research on them, their larval colonies established which are time consuming, then DNA extraction directly from mosquito eggs is easier and less time consuming [5]. Insect fly larvae help in repair and healing its secretion help in breaking fibroblastic aggregation, it removes necrotic tissue by digestion. Some insect maggots have Proteus mirabilis bacteria in their intestine and its secretion have antibacterial effects. Specific type of gauze containing insect secretion used in treatment of wounds in chronic diabetes's and pressure ulcer. Insect derived substance and used in treatment of burns and certain disorders like irritable bowel syndrome, their carbohydrate used in skin diseases and osteoblast and collagen production, lower systolic blood pressure and enhance immunity [6]. Molecular tools are used to efficient typing, identification and surveillance against parasite and other medically important insects, for suitable control and operational research on them [7].

PCR technique is used in insect pest management and biological control, other molecular diagnostic tool are also used for study of insect in the field of identification, systematic and ecology [8].

\section{DNA Extraction Technique}

There are some techniques through which DNA extract in 20 min from coleopteran, Diptera and Hemiptera without any structural damage or discoloration [9]. It has been found that DNA of different small insects with short storage time in $95 \%$ ethanol will be separated more successfully by technique which is simpler, reliable, economical, needs less equipment and reagents. Like cytochrome oxidase I gene (COI) and nuclear gene (Microsatellites) will be separated from Hymenoptera and amplified by PCR [10].

\subsection{DNA Extraction from Vector Insect by Two Alternative Techniques}

Through two different techniques DNA for malarial parasite and vector DNA is extracted, from field collected Anopheles gambiae specimen by capturing through pyrethrum spray the separating their head and abdomen region and placed individually in $1.5 \mathrm{ml}$ micro centrifuge tube with $20 \mu \mathrm{l}$ deionized water, and homogenized to uniform suspension by using sterile pipette tip, $10 \mu \mathrm{l}$ is separated to a autoclaved tube and this separated aliquots used for DNA extraction [7].

\subsubsection{Salting out Technique}

In this technique first add digestion buffer in micro-centrifuge tube then add $5 \mu$ Proteinase $\mathrm{K}$ per $\mathrm{ml}$ of buffer and homogenize the solution and incubate at $55^{\circ} \mathrm{C}$ overnight, in next step vortex the mixture for few sec and then centrifuge the tube at $4^{\circ} \mathrm{C}$ for $2 \mathrm{~min}$ at maximum speed. After that separate the top layer in another tube. And add 0.1 volume of Sodium Acetate with PH 5.2, and after mixing incubate the tube for $15 \mathrm{~min}$ at $-20^{\circ} \mathrm{C}$, then again centrifuge at $4^{\circ} \mathrm{C}$ for $20 \mathrm{~min}$ and separate the top layer in a tube. Then add 2 volume ice-cold $98 \%$ ethanol in tube and mix then incubate for $15 \mathrm{~min}$ at $-20^{\circ} \mathrm{C}$ and incubate at $4^{\circ} \mathrm{C}$ for $20 \mathrm{~min}$, remove the supernatant and add $1 \mathrm{ml}$ of ice-cold $98 \%$ ethanol again and vortex the tube for few sec and centrifuge at $4^{\circ} \mathrm{C}$ for 5 min and again discard supernatant and add ice-cold $70 \%$ ethanol in solution and repeated previous steps and after discard the supernatant dry the remaining in to pelt form which then dissolve in $10 \mu \mathrm{l}$ water or $1 \times \mathrm{TE}$ [11]. 
In salting out technique of DNA extraction, high salt concentration used with phenol and chloroform (hazardous organic solvent) for protein precipitation. Salting out protocol need 10 different reagents for DNA extraction, time required is $2 \mathrm{~h}$ and $47 \mathrm{~min}$ ' and an overnight step included in processing time. The analysis of DNA through PCR revealed 78\% values of sensitivity and specificity [7].

\subsubsection{Chelex Technique}

In this technique separated the specimen and soften it by deionized water, and transfer it in a clean autoclaved 1.5 $\mathrm{ml}$ micro-centrifuge tube. Then add $20 \mu \mathrm{l}$ of deionized water in tube and grind specimen with pipette tube and convert it into suspension, add $100 \mu$ autoclaved $1 \times$ PBS/1\% saponin solution and mix it by vortexing and incubate it at room temperature for $20 \mathrm{~min}$ and centrifuge for $2 \mathrm{~min}$ at 20,000 $\times \mathrm{g}$, discord the supernatant. Then again re-suspend remaining solution (pellet) in $100 \mu \mathrm{l} 1 \times \mathrm{PBS}$, and centrifuge again at 20,000 $\times$ g for $2 \mathrm{~min}$. In next step remove supernatant, re-suspend pellet by $5 \mathrm{sec}$ vortexing in $25 \mu \mathrm{l}$ of $20 \% \mathrm{w} / \mathrm{v}$ Chelex-100 resin suspension in deionized water and $75 \mu \mathrm{l}$ sterile deionized water, and make hole in lid of tube by $23 \mathrm{G}$ hypodermic needle. Boil this suspension on water bath for $10 \mathrm{~min}$ and then centrifuge at 20,000 $\times \mathrm{g}$ for $1 \mathrm{~min}$, and isolate the DNA solution [7].

The Chelex $\left({ }^{\circledR}\right) 100$ resin approach is used to extract DNA from mosquito eggs to identifying their vector approach, population genetic studies and help in monitoring programs. Through this technique even from a single egg substantial amount of mitochondrial DNA is extracted, amplified and sequence as barcode region for identification of species. Although STE is another standard technique used for that purpose gave good amount of DNA. But 260/280 optical density ratio revealed its low quality which prevent its amplification through PCR [5]. This technique required three simple reagents and $37 \mathrm{~min}$ time for complete extraction the Chelex method is simple and sustainable approach in case of rate limiting regiment supply. The analysis of DNA through PCR revealed $100 \%$ values of sensitivity and specificity [7].

\subsection{DNA Extraction from Preserved Insect Specimen}

DNA extraction from preserved specimen is extracted through two different techniques, prepGEM and Charegeswitch. prepGEM technique is new for DNA extraction then Chargeswitch techniques [1].

\subsubsection{Chargeswitch Technique}

This technique is simple, clean and more effective technique for DNA purification. It is water base purification and do not required use of ethanol, chaotropic salts, organic solvents which effect extracted DNA quality, precipitation of DNA which is time consuming step is not used in this technique. This technique work by simple ion exchange mechanism with positively charged at low PH and neutral at PH 8.5 for DNA bind and elute. It simple steps process include cell lyses and addition Charge Switch magnetic beads in solution then lower PH and beads become positively charge and DNA due to their negative charge become attached in the presence of optimized reagents, contaminants removed and DNA elution by increasing PH at 8.5 and ChargeSwitch magnetic beads become neutral [12].

\subsection{2. prepGEM Technique}

Through that technique high quality DNA is extracted from many type of material within 20 min and only used single tube and two simple steps of temperature change. Extracted DNA is free from those inhibitor compounds which prevent PCR. DNA used in analytical and quantitative PCR or in capillary electrophoresis it greatly reduce sample preparation time and risk of contamination. For DNA extraction from wet specimen, 1 - $2 \mathrm{~mm}$ of insect body part is placed in PCR tube then add $35 \mu \mathrm{l}$ of PCR-grade water, $4 \mu \mathrm{l}$ of $10 \times$ buffer BLACK and $1 \mu \mathrm{l}$ prepGEM ${ }^{\mathrm{TM}}$ then incubate at $75^{\circ} \mathrm{C}$ for 15 minutes if need double stranded DNA, in case of single stranded DNA further incubate at $95^{\circ} \mathrm{C}$ for $5-15$ minutes and then centrifuge at $13,000 \times \mathrm{g}$ for 2 min. For dry specimen break up the exoskeleton by forceps and place the tissue overnight at $4^{\circ} \mathrm{C}$ in $40 \mu \mathrm{l}$ of $1 \times$ buffer 3 . Then add $1 \mu \mathrm{l}$ of prepGEM ${ }^{\mathrm{TM}}$ and proceed temperature and centrifuge steps [13].

\subsubsection{DNA Extraction from Preserved Specimen without Physical Damage}

It is now possible that DNA extracted from preserved specimen, in a research DNA extracted from Carabid beetles with preservation age of 2 to 94 years. All precaution are taken to prevent any contamination by foreign 
DNA. preserved specimen is placed in a Eppendorf tube, and then digestion buffer ( $3 \mathrm{mM} \mathrm{CaCl}_{2}, 2 \% \mathrm{SDS}, 40 \mathrm{mM}$ DTT, $250 \mu \mathrm{g} / \mathrm{ml}$ proteinase K, $100 \mathrm{Mm}$ Tris buffer and $100 \mathrm{mM} \mathrm{NaCl}$ ) is added to it with an overnight (16 - 20 hours) incubation at $55^{\circ} \mathrm{C}$ and gentle agitation. Then to stop further digestion specimen removed from the digestion buffer and placed in the 100\% EtOH for 2 - 4 hours and after drying in air it is again placed in collection without any physical damage. And DNA extracted from digestion buffer by its phenol chloroform extraction and then precipitated by treatment with isopropanol, 0.6 volumes $100 \%$ isopropanol, $20 \mu$ g glycogen and 0.1 volume of $3 \mathrm{M}$ sodium acetate are added by gentle vortexing and then centrifuge at maximum speed with $\mathrm{pH} 5.2$ and room temperature for $25 \mathrm{~min}$. Then nucleic acid pellet is removed and washed with $1.5 \mathrm{ml}$ ice-cold $85 \%$ ethanol, twice and dry in air at $65^{\circ} \mathrm{C}$ and re-suspended in molecular biology grade $\mathrm{H}_{2} \mathrm{O}$ [14].

\subsection{DNA Extraction from Fresh Insect Specimen}

To extract DNA from freshly collected insect first frozen them in $1.5 \mathrm{ml}$ centrifuge tube at $-80^{\circ} \mathrm{C}$ [15].

\subsubsection{Puregene ${ }^{\circledR}$ Method}

Take 5 - $10 \mathrm{mg}$ of freshly frozen solid tissues with the help of Gentra Puregene tissue kit. Take the tissues freeze in liquid nitrogen and grind with mortar and pestle. Sustain an ice cold environment for tissues all the time during work. Add $300 \mu \mathrm{l}$ cell lysis solution in a $1.5 \mathrm{ml}$ grinding tube, and then transfer the ground tissues in that tube. Heat the tube for $15-60 \mathrm{~min}$ at $65^{\circ} \mathrm{C}$, to improve the DNA yield add add $1.5 \mu$ l puregene Proteinase $\mathrm{K}$ by inverting 25 times, and incubate for $3 \mathrm{~h}$ at $55^{\circ} \mathrm{C}$ to break all tissues, this step may be extend to overnight (Invert tube periodically) for maximum yield. Add $1.5 \mu \mathrm{l}$ of RNase A solution and invert 25 time, followed by incubation for $15-60 \mathrm{~min}$ at $37^{\circ} \mathrm{C}$. In next step cool the tube by incubating at ice for 1 min and add $100 \mu \mathrm{l}$ of protein precipitation solution and vortex vigorously for $20 \mathrm{~s}$. Centrifuge at 13,000 - 16,000 $\times \mathrm{g}$ for $3 \mathrm{~min}$, protein precipitated in the form of tight pellet or if the pellet is not tight then incubate for $5 \mathrm{~min}$ at on ice and then again repeat centrifugation step. Take $300 \mu \mathrm{l}$ isopropanol into a $1.5 \mathrm{ml}$ microcentrifuge tube and add supernatant which obtain after removal of protein, this process is undertaken by proper care and prevent the dislodged of protein [16].

\subsubsection{DNAzol ${ }^{\circledR}$ Method}

Take 25 - $50 \mathrm{mg}$ of tissues in a loosely fitting, hand held glass-Teflon homogenizer by adding $1 \mathrm{ml}$ of DNAzol, and apply 5 - 10 strokes. Tissues are completely homogenized then store them at room temperature for 5 - 10 min. In next step to remove the partially hydrolyzed RNA, polysaccharides, and insoluble tissues fragments, centrifuge the homogenate for $10 \min \left(4^{\circ} \mathrm{C}-25^{\circ} \mathrm{C}\right)$ at a speed of $10,000 \mathrm{~g}$. In next step to precipitate DNA by adding $0.5 \mathrm{ml}$ of $100 \%$ ethanol per $1 \mathrm{ml}$ of DNAzol, and mix them by inverting tube 5 - 8 time and then incubate it for 1 - 3 min at room temperature. After this step DNA appear in the form of cloudy precipitate, swirl the DNA on the pipette tip by spooling and attached it to the tbe wall or trasfer this material into a clean tube which is store for $1 \mathrm{~min}$ in an upright and remove the waste homogenate from the bottom of tube. If the precipitated DNA is in low concentration then to separate, centrifuge the tube for $5 \min \left(4^{\circ} \mathrm{C}-25^{\circ} \mathrm{C}\right)$ at a speed of $5000 \mathrm{~g}$. in next step wash this DNA twice by adding $0.8-1.0 \mathrm{ml}$ of $75 \%$ ethanol, and inverting tube for $3-6$ times and incubating vertically at room temperature for $0.5-1 \mathrm{~min}$ as a result the DNA is settle down to the bottom of tube and ethanol is removed by pippiting or decating, if DNA is need to free from all contaminents then, wash DNA with 70\% DNAzol and 30\% ethanol solution. In the last step of DNA solibilization add water or $0.2-0.3 \mathrm{ml}$ of 8 $\mathrm{mM} \mathrm{NaOH}$ to approach DNA concentration of $0.2-0.3 \mu \mathrm{g} / \mu \mathrm{l}$. The total time required for this procedure is 10 30 min and DNA recover is $70 \%-100 \%$ which never need any additional purification. DNA obtain by this process is feasible for southern blotting, PCR, Cloning and for other molecular applications [17].

\subsubsection{DNeasy ${ }^{\circledR}$ Method}

After grinding $50 \mathrm{mg}$ tissues by mortar and pestle in liquid nitrogen, transfer the powder in a $1.5 \mathrm{ml}$ micro-centrifuge tube and add $180 \mu \mathrm{l}$ buffer ATL. Then add $20 \mu \mathrm{l}$ of proteinase $\mathrm{K}$ and vortex and incubate at $56^{\circ} \mathrm{C}$ to lyse the insect tissues completely it required $1-3 \mathrm{~h}$, but time vary according to insect species and condition. After incubation the lysate appear viscous. In next step add a solution (200 $\mu 1$ Buffer AL $+200 \mu 196 \%-100 \%$ ethanol) vortex it to homogenize the solution, a layer of white precipitate is appear which may not affect the process of extraction. Then pipet the mixture in DNeasy Mini spin column which is placed in a $2 \mathrm{ml}$ collection tube, and centrifuge for $1 \mathrm{~min}$ at a speed of $8000 \mathrm{rpm}$. After this step discard the collection tube and flow-through and 
again place the DNeasy Mini spin column in a new tube and add $500 \mu$ Buffer AW1 and repeat the previous step of centrifugation. In next step again repeat the previous step but this time this time add $500 \mu 1$ Buffer AW2 and centrifuge at a speed of 14,000 rpm to dry the DNeasy membrane and remove it carefully to prevent carryover of ethanol. After this step all the residual ethanol is removed. In next step place the DNeasy Mini spin column in a 1.5 or $2 \mathrm{ml}$ tube and add $200 \mu \mathrm{l}$ buffer $\mathrm{AE}$ and incubate for one min at room temperature followed by centrifuge at a speed of $8000 \mathrm{rpm}$ to elute the DNA [18].

\subsection{DNA Extraction from Copal}

Copal are semi-fossilized insects specimen, from which DNA is extracted. The Copal specimen sized reduce by trimming and by scalpel, the surface is cleaned by $30 \%$ bleach then by absolute alcohol and DNA-Away, then specimen placed for $5 \mathrm{~min}$, in $5 \mathrm{ml}$ chloroform to dissolve layer of Copal. Then incubate for $48 \mathrm{~h}$ to 8 days, at $40^{\circ} \mathrm{C}$ to remove the resin. Then insect body placed in $2 \mathrm{ml}$ absolute alcohol which is followed by $2 \mathrm{ml}$ UV-irradiated HPLC grade water [3].

Extraction buffer is prepared by $100 \mathrm{mM}$ Tris- $\mathrm{HCl} \mathrm{pH}$ 8.0, $100 \mathrm{mM} \mathrm{NaCl}, 3 \mathrm{mM} \mathrm{CaCl}$, 40 mM dithiothreitol, $2 \%$ sodium dodecyl sulphate, $250 \mu \mathrm{g} \cdot \mathrm{ml}^{-1}$ proteinase $\mathrm{K}$ [3].

When DNA extraction performed, place the insect in $1 \mathrm{ml}$ extraction buffer with gentle agitation at $55^{\circ} \mathrm{C}$ for $20 \mathrm{~h}$. If extraction is destructive then agitation is high and crush the specimen until no large piece remain, and in non-destructive method gentle agitation provided. In destructive method particles after destruction again pass through non-destructive process and at last DNA extracted by using a QiaQuick PCR purification kit. DNA extracted by destructive method is higher in amount then through non-destructive method [3].

\subsection{DNA Extraction from Xylophagus Insect}

For extraction of DNA from xylophagus insects contain high concentration of phenolics, CTAB and modified CTAB-PVP method used. Extraction buffer is prepared by $20 \mathrm{mM}$ ethylene diamide tetraacetic acid (EDTA) with $\mathrm{pH} 8.0$ then add $100 \mathrm{mM}$ Tris- $\mathrm{HCl}$ with $\mathrm{pH} 7.5$ and $1.4 \mathrm{M} \mathrm{NaCl}, 2 \% \mathrm{w} / \mathrm{v} \mathrm{CTAB}, 4 \% \mathrm{w} / \mathrm{v} \mathrm{PVP}-40$ [2].

Specimen grind with nitrogen liquid by mortar and pestle into fine powder, then transfer it into $1.5 \mathrm{~mL}$ tube and add $1 \mathrm{~mL}$ pre warmed extraction buffer at $60^{\circ} \mathrm{C}$, add $\beta$-mercaptoethanol $(2 \% \mathrm{v} / \mathrm{v})$ into extraction buffer before use, and incubate with mixing, for $30 \mathrm{~min}$ at $60^{\circ} \mathrm{C}$. Cooled at room temperature. Then add $2 \mathrm{~mL}$ of RNase and incubate for $15 \mathrm{~min}$ at $37^{\circ} \mathrm{C}$. Add one volume of chloroform isoamyl alcohol, by inversion solution emulsified and then centrifuged at 13,000 rpm for $15 \mathrm{~min}$, top aqueous layer is separated and again treated with chloroform isoamyl and now the aqueous phase is cloudy due to PVP. Then add 2 volume of cold $95 \%$ ethanol $\left(-20^{\circ} \mathrm{C}\right)$ add after mixing incubate it at $-20^{\circ} \mathrm{C}$, DNA strand recovered from the top by Pasteur pipette and washed by $70 \%$ ethanol and centrifuge at 13,000 rpm for 5 min and eluted I sterile analytic graded $\mathrm{H}_{2} \mathrm{O}$ [2].

\subsection{High Molecular Weight Insect DNA Extraction for Cloning}

A new method for high molecular-weight DNA extraction is introduce which does not required CsCl ultracentrifugation, and the entire insect body which is enriched of nuclei is used to extract genomic DNA, by lysing the nuclei and separating the genomic DNA by organic phase separation. This genomic DNA is cleaved by restriction endonucleases and then ligated in cloning vectors to synthesize oligonucleotides in eight different insect species, the time required for the whole process is $24 \mathrm{~h}$ [19].

\section{Factor Affecting DNA Extraction}

Various factor effect the DNA extraction and quality of extracted DNA.

\subsection{Structural Variation of Insect Body}

DNA mostly damage in arthropods specimen which are preserved for morphological identification, and if we extract DNA before preservation then the characteristic which are essential for identification will destroy [9].

\subsection{Extracted DNA Not Belong to Insect's Species}

On the other hand extracted DNA have very little matches and insignificant alignments with other insects, but 
have matches with other organisms like bacteria, proteobacteria and actinomycetes etc. results are unconvincing evidence about DNA preserved in copal, and also raise doubts about DNA extraction from fossils, millions years old then copal [3].

\subsection{Contaminents in Extracted DNA}

DNA extraction from xylophagus (feed on plant) insect is difficult, they contain plant phenolics and tannins, DNA extraction is difficult from digestive tract of adult or if insect is small in size and not easily dissected. DNA from those cells and tissues which are rich in phenolics and tannins. Phenolics and other contaminants cause inhibition in enzyme activates like restriction endonucleases and Taq polymerases, and DNA is not suitable for fingerprinting, genomic libraries construction and for Southern blot analysis [2].

\section{Comparison between Techniques}

All techniques for DNA extraction are equally important, but those techniques which need less reagents like Chelex, Chargswitching, DNAzol and prepGEM techniques are more important. They are cost effective due to small number of reagent and less need to waste management. These four techniques are also rapid extraction techniques and we obtaion DNA within 10 - 40 min (Table 1).

\section{Conclusion}

Advancement in research leads to continuous development of, DNA extraction techniques from insects. Researcher tries to develop an accurate low-cast and rapid technique for DNA extraction. In present, mostly commercially available kits are used for DNA isolation. However, there is not any universal method for DNA extraction exists. Different technique has varying feasibility for DNA extraction from different insect specimen, with different physical condition. DNA extraction from vector insect Chelex technique is more effective then Salting out technique, due to their high quality DNA, short time requirement and much cost affectivity. DNA

Table 1. A brief summary of all techniques discuss in this article.

\begin{tabular}{|c|c|c|c|}
\hline & Techniques & Reagents And Their Number & $\begin{array}{l}\text { Total Time } \\
\text { Required }\end{array}$ \\
\hline 1 & Salting out technique & $\begin{array}{c}\text { Digestion Buffer + Proteinase K + Sodium Acetate + Ice Cold 98\% } \\
\text { Ethanol + Ice Cold 70\% Ethanol + 1XTE Or Water }\end{array}$ & 2 hours and $47 \mathrm{~min}$. \\
\hline 2 & Chelex technique & $\begin{array}{l}\text { Deionize Water }+1 \text { XPBS } / 10 \% \text { Saponin } \\
\text { Solution }+20 \% \text { W/V Chelex } 100 \text { Resin }\end{array}$ & $37 \mathrm{~min}$ \\
\hline 3 & Chargswitching technique & $\begin{array}{l}\text { Chargeswitch Magnetic Beads } \\
\text { (negative at low } \mathrm{PH} \text { and positive at high } \mathrm{PH} \text { ) }\end{array}$ & $10 \min$ \\
\hline 4 & prepGEM technique & PCR Graded water + 10× Buffer BLACK + prepGEM & $20 \min$ \\
\hline 5 & $\begin{array}{c}\text { Extraction from preserved } \\
\text { specimen (special technique) }\end{array}$ & $\begin{array}{c}\text { Digestion buffer }\left[\mathrm{CaCl}_{2}+2 \% \text { SDS }+ \text { DTT }+\right. \\
\text { proteinase } \mathrm{K}+\text { Tris buffer }+\mathrm{NaCl}]+100 \% \mathrm{EtOH}+ \\
\text { phenol chloroform }+100 \% \text { isopropanol }+ \text { glycogen }+3 \mathrm{M} \\
\text { sodium acetate }+85 \% \text { ethanol }+ \text { biology grade } \mathrm{H}_{2} \mathrm{O}\end{array}$ & $\begin{array}{l}\text { Overnight step } \\
+2-4 \mathrm{~h}\end{array}$ \\
\hline 6 & Purgene technique & $\begin{array}{c}\text { Lysis Solution + Purgene Proteinase K + RNase A + Protein } \\
\text { precipitation solution + Isopropanol }\end{array}$ & $33-63 \mathrm{~min}$ \\
\hline 7 & DNAzol technique & DNAzol Solution $+100 \%$ Ethanol $+75 \%$ Ethanol $+8 \mathrm{Mm} \mathrm{NaOH}$ & $10-30 \mathrm{~min}$ \\
\hline 8 & DNeasy technique & $\begin{array}{l}\text { ATL Buffer + Proteinase K + Ethanol + } \\
\text { AW } 1 \text { Buffer + AW } 2 \text { Buffer + AE Buffer }\end{array}$ & $1-3 h$ \\
\hline 9 & $\begin{array}{c}\text { Extraction from Copal } \\
\text { (Semi-fossilized insect body) }\end{array}$ & $\begin{array}{c}\text { Pre-extraction treatment solution } \\
\text { [30\% Bleach + Alcohol+ Chloroform + UV - irradiated } \\
\text { HPLC graded water], Extraction Buffer [Tris- } \mathrm{HCl}+\mathrm{NaCl}+ \\
\mathrm{CaCl}_{2}+\text { Dithiothreitol }+2 \% \text { Sodium dodecyl sulphate }+ \text { Proeinase K] } \\
\text { and then Agitate + QiaQuick PCR kit }\end{array}$ & $\begin{array}{c}\text { Pre-extraction } \\
\text { treatment time } \\
2 \text { - } 8 \text { days }+20 \mathrm{~h}\end{array}$ \\
\hline 10 & $\begin{array}{c}\text { CTAB-PVP } \\
\text { (Extraction from } \\
\text { Xylophagus insects) }\end{array}$ & $\begin{array}{c}\text { Extraction buffer } \\
\text { [EDTA + Tris-HCl }+ \text { NaCl m }+2 \% \text { w/v CTAB }+4 \% \text { w/v PVP-40] } \\
+2 \% \text { v/v } \beta \text {-mercaptoethanol + RNase + Chloroform isoamyl } \\
\text { alcohol }+95 \% \text { ethanol }+70 \% \text { ethanol + analytical graded water }\end{array}$ & 1 hour and $10 \mathrm{~min}$. \\
\hline
\end{tabular}


from preserved insect is extracted through Charge Switch and prepGEM, which are equally suitable but prepGEM is more easier faster and cheaper for freshly preserved specimen (dry or wet) and Charge Switch technique gives more better quantity of DNA for dry specimen with more than 5 years shelf life. Some techniques like for high molecular weight DNA extraction CsCl ultracentrifugation never required. Some modification in basic techniques is also seen, to prevent contaminants and false results from extracted DNA. In other words, scientists try to develop novel cost affective techniques, with more rapid and accurate result.

\section{References}

[1] Ball, S.L. and Armstrong, K.F. (2008) Rapid, One-Step DNA Extraction for Insect Pest Identification by Using DNA Barcodes. Journal of Economic Entomology, 101, 523-532. http://dx.doi.org/10.1093/jee/101.2.523

[2] Nancy, C.-C., Mauricio, Q., Horacio, C.-C. and Guadalupe, Z.-P. (2010) A Simple and Rapid Method for DNA Isolation from Xylophagous Insects. International Journal of Molecular Sciences, 11, 5056-5064. http://dx.doi.org/10.3390/ijms11125056

[3] David, P., Caroline, W., Graeme, F., Sandra, L.K., Richard, F.P. and Terence, A.B. (2013) Absence of Ancient DNA in Sub-Fossil Insect Inclusions Preserved in “Anthropocene” Colombian Copal. PLoS One, 8, e73150.

[4] Behura, S.K. (2006) Molecular Marker Systems in Insects: Current Trends and Future Avenues. Molecular Ecology, 15, 3087-3113. http://dx.doi.org/10.1111/j.1365-294X.2006.03014.x

[5] Freitas, M.T., Gomes-Júnior, P.P., Batista, M.V., Leal-Balbino, T.C., Araujo, A.L. and Balbino, V.Q. (2014) Novel DNA Extraction Assay for Molecular Identification of Aedes spp. Eggs. Genetics and Molecular Research, 13, 87768782. http://dx.doi.org/10.4238/2014.October.27.19

[6] Paul, C. (2010) Bugs and Drugs Part 1: New Alternative Medicine for $21^{\text {st }}$ Century. Alternative Medicine Review, 15, 124-135.

[7] Musapa, M., Kumwenda, T., Mkulama, M., Chishimba, S., Norris, D.E., Thuma, P.E. and Mharakurwa, S. (2013) A Simple Chelex Protocol for DNA Extraction from Anopheles spp. Journal of Visualized Experiments, 71, e3281.

[8] Gariepy, T.D., Kuhlmann, U., Gillott, C. and Erlandson, M. (2007) Parasitoids, Predators and PCR: The Use of Diagnostic Molecular Markers in Biological Control of Arthropods. Journal of Applied Entomology, 131, 225-240. http://dx.doi.org/10.1111/j.1439-0418.2007.01145.x

[9] Castalanellia, M.A., Severtsonc, D.L., Brumleya, C.J., Szitoa, A., Foottitd, R.G., Grimma, M., Munyardb, K. and Grothb, D.M. (2010) A Rapid Non-Destructive DNA Extraction Method for Insects and Other Arthropods. Journal of Asia-Pacific Entomology, 3, 243-248.

[10] Tian, E.-W. and Yu, H. (2013) A Simple and Rapid DNA Extraction Protocol of Small Insects for PCR Amplification. Entomological News, 123, 303-310. http://dx.doi.org/10.3157/021.123.0403

[11] DNA Extraction-Salting out Protocol (2009) Open Wet Ware. http://openwetware.org/index.php?title=DNA_extraction_Salting_Out_protocol\&oldid=368845.E

[12] ChargeSwitch ${ }^{\circledR}$ Forensic DNA Purification Kit. (n.d.) https://www.lifetechnologies.com/order/catalog/product/CS11200

[13] PrepGEM ${ }^{\mathrm{TM}}$ DNA Extraction-Blood. (n.d.). http://www.tataa.com/products-page/dna-extraction/prepgem-dna-extraction-blood

[14] Gilbert, M.T.P., Moore, W., Melchior, L. and Worobey, M. (2007) DNA Extraction from Dry Museum Beetles without Conferring External Morphological Damage. PLOS ONE, 2. http://dx.doi.org/10.1371/journal.pone.0000272

[15] Chen, H., Rangasamy, M., Tan, S.Y., Wang, H. and Siegfried, B.D. (2010) Evaluation of Five Methods for Total DNA Extraction from Western Corn Rootworm Beetles. PLoS ONE, 5. http://dx.doi.org/10.1371/journal.pone.0011963

[16] Gentra Systems (2004) Puregene ${ }^{\circledR}$ Genetic DNA Purification Kit Instructions.

[17] Molecular Research Center (2008) DNAzol ${ }^{\circledR}$ Genomic DNA Isolation Reagent.

[18] Quagen (2006) DNeasy ${ }^{\circledR}$ Blood and Tissue Handbook.

[19] Henry, J.M., Raina, A.K. and Ridgway, R.L. (1990) Isolation of High-Molecular-Weight DNA from Insects. Analytical Biochemistry, 185, 147-150. http://dx.doi.org/10.1016/0003-2697(90)90270-J 